\title{
Caindo na rede
}

\author{
Matemático da Universidade de Notre Dame mostra - sem \\ jargões herméticos e com muito humor - que para compreen- \\ der a ciência, os negócios e a vida moderna é preciso conhecer \\ a extensa teia de conexões que une tudo e todos.
}

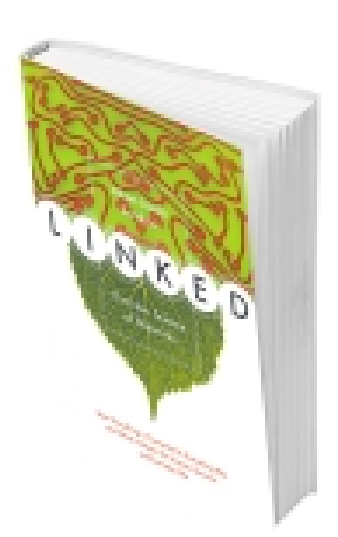

Linked: the new science of networks - how everything is connected to everything else and what it means for science, business and everyday life. Albert-Lászlò Barabási, Perseus Publishing

por Heloisa Pait New School University (NY)

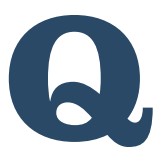
uem nunca ficou olhando para aqueles mapas com rotas de avião nas revistas de bordo? Quem nunca especulou sobre a origem daquela gripe que derrubou todo mundo no trabal ho? E quem é que já não se referiu a um ator como "aquele que trabalhou naquele filme com fulana"?

Esses exemplos mostram nossos esforços para entender o papel das redes no cotidiano: redes técnicas, biológicas e sociais. No primeiro caso, vemos como as rotas de avião formam uma rede que cobre o mundo inteiro. No segundo, mapeamos a disseminação de um vírus a partir de um indivíduo. No terceiro caso, identificamos um ator a partir de associações no mundo cinematográfico. São associações desse tipo que Albert-Lászlò Barabási examina em Linked, recentemente publicado nos Estados Unidos. O livro traça a evolução do pensamento sobre redes desde as primeiras investigações dos húngaros Erdös e Rényi no pós-guerra até as pesquisas mais recentes, que incluem as contribuições do autor.

Barabási conta que, em 1914, a publicação de um conto de Frigyes Karinthy na Hungria deu origem à idéia dos seis graus de separação: no conto, um personagem aposta - e ganha - que pode estabelecer uma relação entre si próprio e qualquer pessoa no mundo, por meio de cinco conhecidos intermediários. Famosa, a história talvez tenha contribuído para o interesse de seus compatriotas sobre 0 assunto. Pelo número denomes com acentos esquisitos mencionados no livro, parece que a Hungria sempre esteve no centro da pesquisa sobre redes, mesmo que hoje muitos desses nomes estejam nas universidades norte-americanas.

A história do escritor húngaro é um dos muitos casos que Barabási conta, tornando a matemática das redes leve e interessante. 0 livro sugere um experimento para descobrir em quanto tempo uma informação espalha-se em uma festa: diga a um convidado que um dos dois vinhos servidos é de uma safra excelente, mas peça discrição. M esmo que o convidado conteo segredo apenas a seus amigos mais próximos, estes vão fazer o mesmo a seus próprios amigos- elogo haverá fila para saborear o melhor vinho.

0 livro traça paralelos entre os fenômenos mais variados, como se as redes da física, da sociedade ou da biologia tivessem propriedades intrínsecas. Grandes aeroportos teriam funções semel hantes às de médicos muito conceituados, que, consultados por muitos colegas, ajudam a divul- 
gar descobertas científicas, assim como os hubs aéreos distribuem passageiros.

Em uma festa na qual ninguém se conhecesse, as redes poderiam se formar aleatoriamente: cada convidado faria contato com mais ou menos o mesmo número de pessoas, sem hubs. Mas para Barabási a maioria das redes não se forma assim: nas empresas, por exemplo, quem já está bem colocado tem mais chances de conseguir um novo posto.

0 conhecimento das redes pode ter usos importantes. A partir da trajetória de contato do vírus HIV, por exemplo, podemos seguir estratégias que dificultem sua transmissão. Se enten demos como se propagam as fal has de transmissão elétrica em sistemas integrados, podemos reduzir o risco de apagões. Pensar em termos de redes também pode ajudar a minimizar os danos ao meio ambiente, protegendo os elos mais importantes das cadeias alimentares.

Pode-se pensar o próprio sistema econômico mundial como uma grande rede, com fluxos de capital, pessoas, mercadorias e informação. As crises dos anos 1990 fazem-nos perguntar se é possível manter moedas nacionais em um ambiente no qual o capital viaja tão rapidamente. Governos transparentes podem minorar as crises criando um clima de confiança entre investidores. Mas desejar eliminálas completamente seria como querer que só seus amigos tomem o vinho bom na festa.

É interessante notar que no pós-guerra o economista inglês John Maynard Keynes empenhou-se em desenhar um sistema financeiro internacional que desse estabilidade a economias cuja crise, anos antes, tinha aberto as portas para a Segunda Guerra Mundial. Em 1936 el ejá identificara o motor da economia contemporâ- nea no jogo de expectativas entre múltiplos agentes. Esse jogo - uma espécie de pôquer financeiro, no qual o queeu penso que vocêpensa queeu penso importa mais que as cartas que de fato tenho na mão forma também uma rede interdependente. Barabási diz que os economistas tradicionalmente viam a ação econômica como uma ação individual de cada agente com 0 mercado; Keynes, que trouxe para a economia a questão da ação interdependente, foi uma brilhante exceção à regra. 0 sociólogo alemão Georg Simmel, por suavez, estudou no início do século XX temas como a individualidade e moda a partir das redes sociais.

Pensar a sociedade como rede implica pensar um mundo de interdependência. As redes são complexas, e muitas vezes seu funcionamento é obscuro. Mas isso não significa que somos peças inertes no jogo do neol iberal ismo ou da global ização. A chance deelegermos um bodeexpiatório para nossos problemas de coordenação reduz-se quando partimos da idéia de que estamos ligados. A maneira de pensar de Keynes, Simmel eBarabási contém um forte elemento ético - um complemento valioso às brincadeiras matemáticas e soluções engenhosas de Linked. 